Dunamis: Jurnal Teologi dan Pendidikan Kristiani

Volume 5, Nomor 1 (Oktober 2020)

ISSN 2541-3937 (print), 2541-3945 (online)

http://www.sttintheos.ac.id/e-journal/index.php/dunamis

DOI: 10.30648/dun.v5i1.309

Submitted: 11 Februari 2020

Accepted: 1 September 2020

Published: 31 Oktober 2020

\title{
The Subject of Education: Disruptive Dilemma in Abraham Kuyper and Ellen White Thought
}

\author{
HalimWiryadinata*; Christar Arstilo Rumbay \\ Sekolah Tinggi Teologia Pelita Bangsa \\ ketua@sttpb.ac.id*
}

\begin{abstract}
The nature of education receives attention and public discussion as it is one dominant core of the cosmological system. However, it echoes to other public squares such as; the state, political power, culture, and religion, contains multi-layered of identity, and against a post-modernism era, which is a very disruptive period that could impact its nature. Abraham Kuyper is known as a public theologian, who offers wide works of education in Europe-Reformed tradition, while Ellen White, a central figure in American-Adventist, even worldwide, contributes unique perspectives. This article conducts qualitative research, attempts to interpret the works of Kuyper and White and reconstructs their idea in order to answer the intention of this research. Eventually, this essay shares the agreement between them concerning God's glorification and adoration as the intention of education, further, demonstrating the diversity where White maintains the holistic approach of education in which Kuyper against it. Moreover, this research attempts to uncover how both figures define the role of state over education.
\end{abstract}

Keywords: religious education; multidiscipline; spiritual formation; holistic education 


\section{INTRODUCTION}

Education, according to Helen Hassolf, performs fluctuation and tension on the matter on the relationship between education and sustainable development, where education has been challenged to contribute to the complexity of social, political and ethical orders. ${ }^{1}$ This is so because sustainable development is considered as one of the greatest challenges to education due to the disruption of the nature of education. ${ }^{2}$ Claes Marmberg commented that the disruptions, where the trainers and learner are considered, do not meet the qualification in the anthropological perspective. Therefore, it may deflect the goals and the development of technology in decreasing social interaction in the learning process. ${ }^{3}$ Michael Flavin, moreover, supported the use of technology, which has been anticipated, would disrupt learning system practices because the educators do

\footnotetext{
1 Helen Hassolf, "The Educational Challege in Education for Sustainable Development: Qualification, Social Change and Political" (Malmo University, 2015), 14.

2 Helen Hassolf, Margareta Ekborg, and Claes Marmberg, "Discussing Sustainable Development among Teachers: An Analysis from a Conflict Perspective," International Journal of Environmental \& Science Education 9 (2014): 41-57.

${ }^{3}$ Beverly Park Woolf et al., "Al Grand Challenges for Education," AL Magazine, 2015.

4 Michael Flavin, "Disruptive Technologies in Higher Education," in Research in Learning Technology, ALT-C 2012, n.d., 102-111.

${ }^{5}$ Bradley Conrad, Christy M. Moroye, and P. Bruce Uhrmacher, "Curriculum Disruption: A Vision for
}

not fully control the virtual learning environments. $^{4}$

Furthermore, the education itself contain disruptive dimension, where Bradley Conrad demonstrated how the curriculum has been the centre of assessment where the meaningful experience of education itself less of attention. ${ }^{5}$ Therefore, it applies to religious education in which the disruptions such as the loss of divine direction. ${ }^{6}$ The sovereignty of a secular state, ${ }^{7}$ furthermore, the modern state in which presents high and large goals. ${ }^{8}$ In other words, these facts guide to the acknowledgement that disruptions exist within and surrounding of education. Identification toward the potential disruption may help to prevent several damages toward education in the discussion of disrupttion in education. According to William Adamson, education is man's natural tendencies, the process of getting knowledge

New Practices in Teaching and Learning," Current Issue in Education 18, no. 3 (2015): 1-20.

${ }^{6}$ See, Angus H. Maclean et al., "The Theological Dillema in Religious Education," Religious Education 55, no. 3 (1960): 163-173.

7 See, M. Agus Nuryatno, "Comparing Religious Education in Indonesia and Japan," Al-Jāmi 'ah: Journal of Islamic Studies 52, no. 2 (2014): 435458. Nuryatno demonstrates how Japan, as a secular state, does not accommodate the subject of religious Education.

8 John Kwame Boateng, "The Role of Education, Religion and Politics in Resolving the Dilemma of the Modern African State," Developing Country Studies 4, no. 2 (2014): 19-25. 
and referring to God, by forcing the process to be actual and effective and he extends his work by supporting the right of a woman and the poor to receive education. ${ }^{9}$ Therefore, the obstacles in his times fall to the issue of gender and proletarian-bourgeois. Further, in his work, he insists that every human being claims the benefits of education, irrespective of rank or sex, for they all are equal in the image of God, equally participants in his grace and kingdom. ${ }^{10} \mathrm{He}$ proposes the universality of education, and education should offer to all human being without any identification.

Abraham Kuyper, a reformed tradition figure, is known as one of the greatest Dutch educator influencers. According to John Witte, Kuyper is the author of several theological works and public theology including the founder of Free University in 1880, an educational institution in which a product of reaction concerning the separation of the church and state. Therefore, he is labelled as the extended educator history in the Netherlands. ${ }^{11}$ However, the tension among state and education under the authority of the church is presented in his context.

\footnotetext{
9 John William Adamson, Pioneers of Modern Education 1600 - 1700 (Cambridge: The University Press, 1921), 58-59.

${ }^{10}$ Ibid, 59-60.

11 John Witte, "The Biography and Biology of Liberty: Abraham Kuyper and the American Experiment," Koers 64, no. 2 \& 3 (1999): 173-195.
}

Therefore, it is demanding to explore his work on state, Education, the potential disruption of state, and uncovered knowledge that probably could offer alternative issue regarding disruption in education. Moreover, one of his popular argument plays on the education and religion where he insists that there is no conflict between them, rather the conflict lays on educators who do not belong divine order and maintain the life of Christian character. ${ }^{12}$ Put it in the different, Kuyper is worthy to receive attention and discussion on his thought in education

On the other side, Ellen White is known as one of the greatest Adventist movement pioneers and contributed to Adventist education are respected and grounded to the history of Adventism. In 1782, she performed a large number of writings, the importance of education, practical Education, mental and spiritual aspect, and the importance of balancing in education. ${ }^{13}$ She offered the best method of educational goals for society and balance counsels to the state. However, her main focus falls to the centrality of God's salva-

\footnotetext{
12 Nicolaas Gronum and Fika Janse VanRensburg, "Abraham Kuyper's Christian Science and Empirical Science - Different yet Similar: An Investigation into Epistemological Structures," In die Skriflig 48, no. 1 (2014): 1-8.

13 George R. Knight, "The Aims of Adventist Education: A Historical Perspective," in Adventist Education, General Conference, 2000, 6.
} 
tion work in education. She highlights the importance of a holistic approach and therapeutic development. ${ }^{14}$ Therefore, as an American Adventist education influencer, White's works on education are worthy of gaining attention and evaluation; further, the intention here is, to compare the knowledge of Kuyper and White concerning their thought on education in accordance to their context. The conversation regarding disruptions in education from them is interesting to be discovered due their knowledge are expected will testify alternative contributions to the issue discussed.

The research question that leads this essay is: What are the disruptive dilemmas in education, according to Abraham Kuyper and Ellen White? How do Abraham Kuyper and Ellen White describe errors in education? What comparisons are possible to be made by those figures? What reflection can they offer that about the disruptive dilemma in Education?

\section{RESEARCH METHOD}

This study conducts qualitative research, evaluating the original works of Abraham Kuyper and Ellen White, and describing their thought on the disruptive

\footnotetext{
14 G.H. Akers, "Proper Education," in Adventist Education, General Conference, 1989, 8.

15 James D. Bratt, ed., Abraham Kuyper: A Centennial Reader (Michigan, Grand Rapids:
}

dilemma in education. A sensitive interpretation approach will evaluate their works. The analysis shall proceed on descriptive and analysis basis. Afterwards, re-structure their thinking in order to give critics and gains contributive idea from them. In the next stage, this essay tries to construct conversation between Kuyper and White in order to display the similarity, diversity and positive donations for the tension. Lastly, a conclusion will be grounded based on the analysis of their thoughts.

\section{RESULT DAN DISCUSSION}

\section{Abraham Kuyper}

In his public address delivered at the inauguration of Free University, entitled "Sphere Sovereignty," Kuyper argues that the nation struggles with a crisis, in a narrow sense, the purification of religious influence took place at education square. ${ }^{15}$ However, the intention here specifically addressed to the state, continuously in his works, Kuyper gives attention to the role of the state and church. Therefore, implicitly, he insists that education should stand as a single discipline without any intervention, separation of education receives considerable attention because, in his mind, sphere

William B Eerdmans Publishing Company, 1998), 464. 
sovereignty refers to a society that made up by various spheres which are family, art, science, and not derived the authority, not from the state. ${ }^{16}$ However, Kuyper gives superiority to the state, assuming that the state is the leading sphere due to the constitution of the law by setting boundaries of the other spheres. ${ }^{17}$ Consequently, edu-cation, as part of the state dimension, submits to the authority of the state. The state formulates codes and regulations to maintain the harmony of its citizen. There-fore, the existence of education is required to follow the direction of the state.

Moreover, Kuyper places the state into special attention, a sphere of spheres, which encircles the whole extent of human life. ${ }^{18}$ With this in mind, the dilemma of education is strongly related to the state. It sets up the boundaries and freedom of education and applied to certain states present time. Indeed, Netherlands has different tradition and issues that may not equal to

\footnotetext{
${ }^{16}$ Peter S. Heslam, Creating a Christian Worldview: Abraham Kuyper's Lectures on Calvinism (Grand Rapids: Eerdmans, 1998), 154.

17 Timothy Saun Price, "Abraham Kuyper and Herman Bavinck on the Subject of Education as Seen in Two Public Addresses," TBR 2 (2011): 5970.

18 Bratt, Abraham Kuyper: A Centennial Reader, 472.

${ }^{19}$ Education in the Netherlands less focus to the gifted and talented students, further, top universities have no place due the equality is profoundly
}

another context, ${ }^{19}$ nevertheless, his notion opens the perspective of Christian scholars that the similar issue may against the postmodern era. For some cases, the state limits latitudes of each sphere, and possible to resist education activities, leads the religious influence commits to vacuum toward society.

Education stands as a single sphere and separated from others, remain to its sphere, and vital as creates a sphere in which truth reign supreme. The scholarship does not search its own sake, rather, uncovers God's wisdom and expresses into human thought and language, even it has no benefits for personal lives. ${ }^{20}$ The intention should be ended in the adoration to God, ${ }^{21}$ God, as the leader of all sovereignty, reserve the exaltation and glorification, education should direct back to God. Further, even stand as a single, separated sphere, every sphere is possible of contradiction and conflicts, and this tendency attacked attention to Kuyper, one sphere

presented. See, Greet C. DeBoer, Alexander E. M. G. Minnaert, and Gert Kamphof, "Greet C. De Boer, Alexander E. M. G. Minnaert, and Gert Kamphof," Journal for the Education of the Gifted 36, no. 1 (2013): 133-150.

${ }^{20}$ Abraham Kuyper, Wisdom and Wonder: Common Grace in Science and Art, ed. Jordan J. Ballor and Stephen J. Grabill (Grand Rapids, Michigan: Christian's Library Press, 2011), 93.

21 Bratt, Abraham Kuyper: A Centennial Reader, 476. 
that may encroach on its other neighbour. ${ }^{22}$ He suggests then, the mutual interaction between spheres, especially speaking, education and another related discipline should receive attention, positively, however, it constructs relations to other disciplines, squares and possibilities. Therefore, the communication between education and other spheres will lead to either a positive or negative contribution.

Furthermore, Kuyper maintained the existence of a science of the unbelieving world, arguing that the real knowledge comes from secular scholarship, construct the foundation of its principles. Further, he offers optimistic calling to Christian to examine and correct, if possible, performs criticism. Confidence that renovation and restructuration by the scientific world to the knowledge probably would contribute. Using biological terminology, he continues, that unnecessary branches may be cut off in order to defend the truth. ${ }^{23}$ With this in mind, Kuyper argued that education must be rooted in something, laying to a certain position, or otherwise, it is idle. Education should be tested and exercised through the scientific process. An effort to place Education free from other disciplines, poten-

\footnotetext{
22 Ibid, 468.

${ }^{23}$ Ibid, 479.

${ }^{24}$ Gordon Graham, ed., The Kuyper Center Review, Volume 5: Church and Academy (Cambridge, UK:
}

tially earning twofold errors. ${ }^{24}$ In the other word, dangers follow by divorcing scholarship off of the secular world, the dilemma takes place, either to purify education, stand as a single branch separate from other disciplines, or deciding to employ contributive disciplines that could benefit Christian education. Therefore, the suggestion here is, faith and the counsels of God should be united, ${ }^{25}$ Education can maintain its original divine order with or without secular science. Faith offers deep conviction to Christian thinkers, and God's advises lead its direction. However, according to Kuyper, investigating certain subject without or less of a starting point or scientific evaluation is impossible. Further, he argues that the engagement of secular sciences, all systems, or confessions help to reach higher achievement in education. Here, another disruption comes, when the distinction between lower and higher science increasingly ignored where Kuyper draws clear classification. Truth without experiencing scientific assessment is the province of lower science, and higher science goes beyond the truth. The danger is, when observation plays no significant role over science, it will

William B Eerdmans Publishing Company, 2015), 136.

25 Abraham Kuyper, Lectures on Calvinism (New York: Cosimo Classics, 2007), 115. 
lead to false emphasize on truth, and misconstruction on the human mind. ${ }^{26}$

Moreover, a striking conclusion of Kuyper, assuming that Christian Education itself carries special dangers because he doubts that scientific process and observation do not have a place in Christian Education, and where exclusivism brings dogmatism to such dilemma. In reaction to the science, it should be started by disagreement and any prompt dissent in order to seek truth, objectivity and impartiality. ${ }^{27}$ Where Christian allegiance commits to certain absolute truth, in secular education sense, doubts are the leader of scholarly inquiry that may offer alternatives to universal problems and questions. In contrast, some specific identity of Christian allegiance relates to undoubted matter, received as the truth that needs no more clarification. ${ }^{28}$ Of course, the examination takes place in the core of Christian faith, but the intention is to develop the beliefs, and not to shake or re-arrange the core of the doctrine.

\footnotetext{
${ }^{26}$ Graham, The Kuyper Center Review, Volume 5: Church and Academy, 138.

${ }^{27}$ Ibid, 139-140. Kuyper assumes truth as the lower level of science due he doubts on the educational process in which passed by the truth itself. Therefore, false enforcement of truth consequently leads to such misconstruction and miss-framework of knowledge. Here he suggests that truth must experience the reality of the scientific process to avoid any disruption in Education.
}

Furthermore, another discussion, the connection of state to education has predominantly attacked the intention of Kuyper. Consistently, he speaks the mutual relationship of the state and scholarship. The discussion is required to connect the spheres. However, the dilemma is, for some case, the appearance in scholarship activities are extremely needed, such as financial support and others, but an intensive influence may disrupt the existence and major intention of education. Kuyper's attention falls to the role of state over scholarship. However, he believes that all human race is from one blood. ${ }^{29}$ It implies the similar purpose and motivation of all division in the world and should be authorized by a certain contingent where each group are expected to share a mutually beneficial relationship. Nevertheless, Kuyper against education running under control by the state becomes a servant of the state, and tool to achieve any purpose, even though the state is acknowledged as the authorized institution. For instance, in some

\footnotetext{
${ }^{28}$ For instance, in certain fundamental Christian such as Adventism, has no doubt concerning the authority and originality of the bible and against any effort to re-question the position of the bible for believers while liberal Christians start with doubt to discover the scientific truth. Please see the statement of faith of Seventh Day Adventist Church (https:// www.adventist.org/beliefs/).

${ }^{29}$ Kuyper, Lectures on Calvinism, 79.
} 
cases, the state employs education to reach the political purpose. In contrast, scholarship should pour and disseminates the knowledge into state and other spheres. ${ }^{30}$ The logic here is, education is an account who owns the responsibility to participate into other disciple and impact its positive contribution where the state presented as the object who will receive exercise and not the state who performs influence to education. It seems Kuyper exclusively refer the state as a subject of discussion in which contains a dilemma about its significance and role over education. The existence of a state is the ultimate focus, place of tensions and dilemmas, demands efforts to explore its nature. Therefore, in his other works, Kuyper discusses the relationship between the state and church, intends to uncover the role of state over other spheres. In sum, as a public theologian, he examines the state as a potential disruption could bear a dilemma to the encircle of scholarship sphere.

\section{Ellen White}

White's attention to education served in her work, namely, education. This

\footnotetext{
${ }^{30}$ Price, "Abraham Kuyper and Herman Bavinck on the Subject of Education as Seen in Two Public Addresses," 62.

31 John Skrzypaszek, "The Higher View of Education," https://research.avondale.edu.au/cgi/ viewcontent.cgi article $=1068 \&$ context $=$ teach .

32 Ellen White, Education (United States: Ellen White Estate Inc., 1903), 13.
}

treatise occupies segments of scholarship. The introduction, an opening of her writing, begins with an emphatic statement, ${ }^{31}$ she refers to education beyond than a course of study,${ }^{32}$ it does not only contains knowledge and math, physics, and commercial formulation, rather, but also turns into the complexity of its scope, and jump to the main heart of education itself in which takes narrow and low of the range. This means, jumping directly to the core of education will lead to the minimum advantage. Disruption degrades its values by simply regards pursuing certain core of courses as the ultimate purpose of scholarship. Furthermore, White insists that education is related to the whole being and period, related to the harmony of physical, mental and spiritual. ${ }^{33}$ In other words, she offers a holistic approach rather than focusing on a certain dimension. ${ }^{34}$ Several notions, aspects and layers formulate education. Therefore, to gain the advantages of education, it requires a comprehensive approach, a combination of multi-layered segments. ${ }^{35}$ Recent research agrees with the

\footnotetext{
${ }^{33}$ Ibid.

${ }^{34}$ Karin Gnaroe, "Maria Montesori and Ellen White: A Comparative Study," https://www.grin.com/ document/322732.

${ }^{35}$ In her writings, Ellen proposes the importance to involve social concern, character, physical and other related sources that may help the development of Education itself. Therefore, she against any attempt
} 
position of White by demonstrating the needs and effects of other dimensions such as social development, culture, and state to education, together with its complexity. ${ }^{36}$

Furthermore, White insists that education who receives limited definition consequently minimize its notions and echo. However, it contains broad sense and possesses meanings that could help a human being. Separating education into sub-division leads to the weakness of its magic, she aligns the needed of every human element, the equality of physical, mental and spiritual, by which she meant education in matters of healthful living, household duties, and other practical lines of work. ${ }^{37}$ In the other work, she proposes a holistic approach of study, involving minor dimen-sion that would help the construction of education. For instance, education who deal with real discussion needs the involvement of certain theories that will support the argumentation of physical exercise. How-ever, it seems that she does not exclusively focus to a certain aspect in

to develop Education without involving other disciplines. See, Ellen White, Counsels to Parents, Teachers, and Students, 1913, 64, 307-308, Testimonies for the Church, 1889, 5:522, The Youth's Instructor, April 7, 1898, Testimonies for the Church, 1880, 4:418, and Fundamentals of Christian Education, 186.

${ }^{36}$ Rodica Mariana Niculescu and Mariana Norel, "Religious Education an Important Dimension of Human's Education," Procedia-Social and Behavioral Sciences 93 (2013): 338-342. order to describe the nature of education, and indirectly, she argued the potential danger of scholarship grouping, holistic attention should be running in order to achieve the significant meaning of education.

However, it is not the ultimate aims of education, Knight suggests that it is not the central point of White. Leading the multitude to God and construct a connection to Christ are the main purpose. ${ }^{38}$ With this in mind, it seems that White tries to weaken the intellectual and physical preparation by giving a large portion of attention to God as the centre of educational purpose. Instead, she insists that concern to God should follow over-attention to physical and mental. This idea relates to the following argument of Ellen, where she insists that the ultimate intention of education submit to divine power. The danger comes when spending too many energies to a certain aspect, or single effort to intellectual alone, or physical preparation, but ignore the involvement of

\footnotetext{
${ }^{37}$ Erling Bernhard Snorrason, "Aims of Education in the Writing of Ellen White" (Andrews University, 2005),

https://digitalcommons.andrews.edu/cgi/viewconte nt.cgi article $=1706 \&$ context $=$ dissertations .

38 George Knight, Myths in Adventism: An Interpretive Study of Ellen White, Education and Related Issues (Hagerstown, MD: Review and Herald, 1985), 49-51.
} 
divine order. Education is a holistic concept that refers and direct to God as the final intention, improving the rela-tionship between students and their God, directs human minds to Gods own re-velation. ${ }^{39}$ In sum, all of the dimension in which presented as the materials of edu-cation intends to construct a proper frame-work of thinking that should lead people to God. Motivation, intention, and application are directed to God's glory. The science of law, business, politics and other main disciplines were equipped as tools to reach divine order.

The crisis appears in the concept of centeredness and the final destination. Consistently, White employees the involvement of God in her thought while in the contemporary thoughts, people do disoriented and loss the center point of education. Here is suggested, the highlighted themes from the heart of White's thought on disruptive dilemmas in education, centeredness vacuum and distortion of the end purpose. In other words, she suggests the involvement of divine intention to the activities of education. For instance, the activity of law science should be grounded on scripture order where the code of criminal law is equipped. The ultimate

\footnotetext{
${ }^{39}$ White, Education, 16.

${ }^{40}$ Ibid, 14.
}

purpose of business must be directed to the concept of God-center in order to fulfil the divine order. The absent of centeredness of God in education leads to potential disruption.

Furthermore, White gives attention to the nature of man, the purpose of creation by God. ${ }^{40}$ In the human side, the dilemma exists where human being avoids to examine their existence. It is strongly related to the knowledge of education. Because the coming of evil knowledge may affect the true nature of education itself, opens the possibility of distortion in which generate disruption and dilemma. In the other side, knowing the nature of God in scholarship could help to gain the whole picture of its meaning. Investigating the role of divine order toward secular education leads to a comprehensive understanding of the core meaning of education. God is love, and love is the very foundation of Education. ${ }^{41}$ In short, she emphasizes that the basis of education itself is God alone, as God is love. She is very dramatic-melancholic in describing education on deity side. Her investigation plays the whole aspect of the universe, resists to focus on single purpose and object. Besides, by connecting to the topic of love, the indication is, she lays her

\footnotetext{
${ }^{41}$ Ibid, 15.
} 
thought of education in the redemption work of Christ, because consistently the theme of love related to cross event.

Furthermore, according to White, the highest sense of education and redemption are one, which is Jesus Christ, even under changed conditions, it still conformed to the Creator's plan. ${ }^{42}$ Here, it is clear, and the disruption takes place where the nature of man and God are empty and less attention. Furthermore, her argument implies to soteriological sense, because besides love, a romantic expression, redemption work relates to the end purpose of human being, salvation, and tend to miss the common sense of education. Of course, this idea contrasts to general notions and against clearly secular knowledge.

However, White's tone is fanaticism, since she refers exclusively to infinite God alone as the main source. ${ }^{43}$ She tends to be pessimistic toward secular and worldly knowledge, in fact, however, investigating the divine being and matter required the support of other disciplines. In contrast, generally, White uses the term of education holistically, speaking of comprehensive education. Nevertheless, the mean of holistic and comprehensive need more clari-

\footnotetext{
${ }^{42}$ Ibid, 31.

${ }^{43}$ Ibid, 13.

${ }^{44}$ Skrzypaszek, "The Higher View of Education."
}

fication since White is exclusive, fanatic and seems totally against secular knowledge. Does she mean holistic in term of religious scope, or, further, extend to its neighbours, other disciplines? Since she proposes the similarity of physical, spiritual, and mental development, then it could be acknowledged that she refers to holistic Education in the general sense, accommodating other squares.

In conclusion, besides the centeredness and dis-oriented of destination, the dilemma in education occurred in the rejection of transformation. Education requires incarnation and progression, demands transformational qualities and occupies deep incarnational meaning. ${ }^{44}$ It is an engagement of people who expect the progress of alteration into God's great plan. The effect of avoiding incarnational in education results errors and potentially may disrupt the core concept of education. However, this idea is supported by Loxburgh and Romaniuk, where they say that Jesus draws people into a new imagination about the nature of the good news he incarnates. ${ }^{45}$ In other words, the emptiness of incarnational in Education offers a dilemma and disruptive toward scholarship itself.

45 Alan J. Roxburgh and Fred Romanuk, The Missional Leader: Equipping Your Church to Reach a Changing World (San Francisco, CA: Jossey-Bass, 2006), 75 . 


\section{Discussion}

In order to ground clear ideas on how Kuyper and White regard the disruption in education, here below prepar-ed a table that could help to echo a general idea and follows by description and expla-nation of the table.

\begin{tabular}{|c|c|c|c|c|}
\hline No & Name & $\begin{array}{l}\text { Ultimate Intention } \\
\text { of Education }\end{array}$ & $\begin{array}{c}\text { The Relation Between the } \\
\text { State and Education }\end{array}$ & $\begin{array}{l}\text { The Intervention of } \\
\text { other Disciplines }\end{array}$ \\
\hline 1 & $\begin{array}{l}\text { Abraham } \\
\text { Kuyper }\end{array}$ & $\begin{array}{l}\text { God's adoration and } \\
\text { glorification }\end{array}$ & $\begin{array}{l}\text { Extreme action to separate } \\
\text { the state and education, sees } \\
\text { the possibilities of the state } \\
\text { of being disruptor toward } \\
\text { education and contributes } \\
\text { large portion discussion on } \\
\text { the subject of state }\end{array}$ & $\begin{array}{l}\text { Against any combi- } \\
\text { nation of other disci- } \\
\text { plines that may disrupt } \\
\text { the core value of edu- } \\
\text { cation }\end{array}$ \\
\hline 2 & $\begin{array}{l}\text { Ellen } \\
\text { White }\end{array}$ & $\begin{array}{l}\text { God's adoration and } \\
\text { glorification }\end{array}$ & $\begin{array}{l}\text { Less attention to the state and } \\
\text { give more effort to the } \\
\text { spirituality and divine order }\end{array}$ & $\begin{array}{l}\text { Occupying large parti- } \\
\text { cipation of other disci- } \\
\text { plines offers a holistic } \\
\text { approach }\end{array}$ \\
\hline
\end{tabular}

Exclusively, Kuyper demonstrates the role of state over education. He extremely intends to separate the intervention of the state, clear any involvement that may result from independence. Even though the state is a superior sphere, but education should free from any entanglement. However, the interaction between education and the state has been shaped, especially a country where industry and modernism presented. Moreover, a state in which the education being united with the government

46 Charl Wolhuter and Corene de Wet, eds., International Comparative Perspectives on Religion and Education (Bloemfontein: Sun Press, 2014), 2. Charl supplies examples on how the United State, the geography and anthropological context of White, and France, dealing with the education reformation of mass education institutes by secularizing the curriculum. Further, please see Harry Anthony usually named as secularism. ${ }^{46}$ However, Kuyper strongly resists the idea of a state's participation toward a scholarship. In the other side, White treats education in complexity. She offers a holistic approach and occupies large and wide aspects that related. She against any effort to narrow the original sense of education because its nature contains heterogenic matters. Concerning the dialogue between them, White has less attention to the role of the state, the consequence is, she does not view govern-

Patrinos, School Choice in the Netherlands, 2011, 55., where the present time in the Netherlands, most of the schools are running by private school boards. However, it has a strong connection with Kuyper where he insisted the separation of state and school, see Graham, The Kuyper Center Review, Volume 5: Church and Academy. 
ment as a warning that may disrupt the nature of education as Kuyper did, as she consistently to spend her focus on the religious-spiritual purpose. However, awareness emerges as a religion in Education has been a controversial subject worldwide. It could lead to a division that may not prevent conflict and lack of agreement of interreligious society. ${ }^{47}$ Of course, besides the danger, exclusive attention to religion intention offers glues of heterogenic religious society as well, because the expectation is; respecting the difference, understanding adherents believe and making meaning of life, that would develop empathy. ${ }^{48}$

Here is presenting, the distinction of them is clear, in Kuyper's side, the disruption falls to the effort of combining or connecting some elements which are possessing contrast intention to education aims and harms its independence. Instead, White expresses the danger of evaluating education alone without a comprehensive action, errors are possible when examination takes place, but a holistic approach is a vacuum and the losing of bringing the human mind to God. Furthermore, as

\footnotetext{
${ }^{47}$ Wolhuter and de Wet, International Comparative Perspectives on Religion and Education, 1.

48 Joyce Miller, Kevin O'Grady, and Ursula McKenna, Religion in Education: Innovation in
}

Kuyper discusses a large portion in the theme of state, White gives attention to the spiritual sense. However, of course, Kuyper is known by his masterpiece contributions in public theology; his background as theologian-politician influence his works. In the other side, White did not involve in any activity that relates to the state. Therefore, her concern does not fall into a mutual connection of state-church in the sense of education. Further, her stem tends to describe the nature of religious education. Consequently, Kuyper offers a dilemma in education related to the sovereignty of the state while White consistently evaluates the errors of education in the sense of religious square.

In reaction to their arguments, concerning the connection between stateeducation and religion-education, Jackson views the danger of religious isolation, confrontation and instrumentalization to education that may not contribute intercultural dialogue, tolerance and harmony. ${ }^{49}$ A solution needs to be discovered to offer a neutral position in the disruptive education era as the dilemma could be prevented by putting exist by putting education in a

International Research (London: Routledge Taylor \& Francis Group, 2013), 198.

49 Robert Jackson, Religious and Education in Europe: Developments, Contexts and Debates (Munchen, Berlin: Waxmann Munster, 2007), 267. 
proper balance spot between the state and divine purpose. Even more, Hansenclever extends the claim by making a clear distinction between education with divine intention and political power of the state, by saying, the lesser of religious education, the more political mobilization could employ scholarship as a tool to achieve its destination. ${ }^{50}$ Even more, a state's investment intends to reach significance influence over Education in which may danger its independence. ${ }^{51}$ As the alternative, education should be placed in the centre of tensions which still possible to stand as an independent institution but able to engage with the government without disrupting religious intention. An unbalance treating opens the possibility of education subtraction. Reformation, the involvement of the state toward education, needs attention, including the frequency of religious participation for the independency of education.

The comparison and the discussion concerning the disruptive dilemma fall to the role of a heavenly and worldly kingdom. Kuyper spends his attention to the role of state over education, he resists any invol-

50 A. Hasenclever, "Geteilte Werte, Gemeinsamer Frieden? Uberlegungen Zu Zivilisierenden Kraft Von Religionen Und Glaubensgemeinschaften," in Friedenspolitik: Ethisce Grundaglen Internationaler Beziehungen (Munchen: Piper, 2003), 204.

51 John Simmons, The Education Dilemma: Policy Issues for Developing Countries in the $1980 \mathrm{~s}$ vement of state that may lead to unneutrality, even further, employed to gain certain destination. ${ }^{52}$ The use of education as a means to achieve worldly kingdom intention is very dangerous and may disruptive. In contrast, White diligently refers to the heavenly kingdom as the predominant and ultimate purpose. ${ }^{53}$ The absence of divine intention is a dilemma as well as the involvement of practical purpose, and attention should be placed in order to prevent any annoying subjects.

However, even though Kuyper demonstrates the tragedy of education, specifically to the participation of government, as he delivered his speech in the inauguration of Free University, but it does not mean that Kuyper against God's intervention into Education. Indeed, his penetration begins with state evaluation, but end into adoration to God. ${ }^{54}$ It proves that Kuyper gives equal attention to both issues, he is not so conservative on the role state, but provide few analyze to the Master Teacher, God himself. Nevertheless, still, his extremism to education independence remains a space of engagement with other

(Oxford, New York, Toronto, Sydney, Frankfurt: Pergamon Press, 1980), 3.

52 Price, "Abraham Kuyper and Herman Bavinck on the Subject of Education as Seen in Two Public Addresses," 62.

${ }^{53}$ White, Education, 16.

${ }^{54}$ Bratt, Abraham Kuyper: A Centennial Reader, 472. 
spheres, because it is important to gain support from surrounded to achieve its intention. In the other word; treating education as a single square alone, the emptiness of cooperation, and avoiding divinity purpose, are tragedy and error.

On the other side, White has a similar destination, as Kuyper expressed, the main heart of education ends in the divinity attention. The multitude should be directed to God's revelation. ${ }^{55}$ With this in mind, it means that the whole segmentations, the comprehensive elements, must be led to God. These evaluations lead us to a temporary conclusion, that the agreement between Kuyper and White exist, putting away God as the final destination could disrupt the subject of education. Nevertheless, in the sense of preparation, they are in diversity, because Kuyper gives attention to the purification of secularity or state involvement and the engagement to surrounded disciplines should take place in order to gain the ultimate purpose ${ }^{56}$, While White less attention to any preparation, rather focus on bringing human minds to God. ${ }^{57}$ In conclusion, the danger is, in Kuyper's thought, the loss of any preparation, and White argues that the urgency

\footnotetext{
${ }^{55}$ White, Education, 16.

56 Bratt, Abraham Kuyper: A Centennial Reader, 464.

57 White, Education, 16.
}

of bringing back human minds to God without specific intention to preparation is needed.

Furthermore, Kuyper is more optimistic concerning the engagement of secular education because it is needed in order to have a certain starting point. Besides, usually, disagreement leads to the truth where the destination of education is seeking the truth. ${ }^{58}$ In contrast, even though White employs the importance of a comprehensive approach, but she is pessimist toward secular scholarship methods. Indeed, she demonstrates the role of holistic education $^{59}$ Nevertheless, it does not encompass its neighbours, in short, playing around religious education without attention to outbox disciplines. Egocentrism plays dominantly in her work; she stems in a privileged position and focuses on its true nature education. Any engagement to secular disciplines does not gain attention. However, dangers are possible to her treatment as the truths gained do not scientifically accepted. Scientific assessment, seeking truth, demands a certain method to achieve its genuine truth. Kuyper is open to this approach where White does not speak too much.

\footnotetext{
${ }^{58}$ Graham, The Kuyper Center Review, Volume 5: Church and Academy, 138.

59 Gnaroe, "Maria Montesori and Ellen White: A Comparative Study," 27.
} 
In short, Kuyper argues the danger of education deep engagement to other disciplines, specifically speaking, the state, while White views the weakness of partial treatment. Here is, Freire offers alternatives to their discussion concerning division and holistic approach, in order to prevent such disruptive dilemma, he agrees with White, suggests to move beyond, searching the original meaning, and a struggle of power relation. ${ }^{60}$ Unfortunately, he does not extend his notion, so it may be applied broader. However, for White, it is undebatable, the natural meaning, even beyond, refers to God's mind, and the power of relation translated in the holistic approach. However, Freire gives an equivalent portion to both Kuyper and Ellen, as he supports Kuyper's idea about the relationship and distinction of the state and education. In his discussion, Freire demonstrates that education represents the passion for making the states more pedagogical because political power has the project to develop a deep and abiding faith in the struggle of humanizing. ${ }^{61}$

\section{CONCLUSION}

The disruptive dilemma is the investment of government to the educational

\footnotetext{
${ }^{60}$ Henry A Giroux, "Introduction," in The Politics of Education: Culture, Power, and Liberation (United
}

process and the loss of final spiritual attention. However, Kuyper agrees with White concerning the end intention of education is directed to God's glorification and adoration, in the other word, the danger exists if education stands separately with the religious matter or the divorcement from heavenly kingdom destination. Further, regarding the intervention of the state, Kuyper gives attention to the danger of the participation of government since it will control and mobilize education, consequently, it loses its independence. Nevertheless, it does not mean that Kuyper against any secular approach as another danger will come by treating so. Science approach could be both dilemma and opportunity because the absence of secularism method is truly danger as education need a formula in order to reach the truth. However, on the other side, the scientific approach would harm the positive output of religious education such as tolerance, harmony and concord. Furthermore, regarding holistic and division approach, Kuyper and White are in diversity. The tone of White is more open as she suggests a comprehensive and holistic approach while Kuyper insists on the

States of America: Bergin \& Barvey Publisher Inc., 1985), xiii.

${ }^{61}$ Ibid. 
purification of education of any influences.

These mean, either partial or holistic approach consist of dangers that may disrupt education, the dilemma takes place concerning to treat education partially or comprehensively.

\section{ACKNOWLEDGEMENT}

I would like to say thank you for Christar A. Rumbay, who contributes his analysis on the idea of Allen White and thoughtful comments throughout this research. Your contribution is extremely valued for the perfectness of this article.

\section{REFERENCES}

Adamson, John William. Pioneers of Modern Education 1600 - 1700. Cambridge: The University Press, 1921.

Akers, G.H. "Proper Education." In Adventist Education, General Conference, 8, 1989.

Boateng, John Kwame. "The Role of Education, Religion and Politics in Resolving the Dilemma of the Modern African State." Developing Country Studies 4, no. 2 (2014): 19-25.

Bratt, James D., ed. Abraham Kuyper: A Centennial Reader. Michigan, Grand Rapids: William B Eerdmans Publishing Company, 1998.

Conrad, Bradley, Christy M. Moroye, and P. Bruce Uhrmacher. "Curriculum Disruption: A Vision for New Practices in Teaching and Learning." Current Issue in Education 18, no. 3 (2015): 1-20.
DeBoer, Greet C., Alexander E. M. G. Minnaert, and Gert Kamphof. "Greet C. De Boer, Alexander E. M. G. Minnaert, and Gert Kamphof." Journal for the Education of the Gifted 36, no. 1 (2013): 133-150.

Flavin, Michael. "Disruptive Technologies in Higher Education." In Research in Learning Technology, ALT-C 2012, 102-111, n.d.

Giroux, Henry A. "Introduction." In The Politics of Education: Culture, Power, and Liberation. United States of America: Bergin \& Barvey Publisher Inc., 1985.

Gnaroe, Karin. "Maria Montesori and Ellen White: A Comparative Study." https:// www.grin.com/document/322732.

Graham, Gordon, ed. The Kuyper Center Review, Volume 5: Church and Academy. Cambridge, UK: William B Eerdmans Publishing Company, 2015. Gronum, Nicolaas, and Fika Janse VanRensburg. “Abraham Kuyper's Christian Science and Empirical Science - Different yet Similar: An Investigation into Epistemological Structures." In die Skriflig 48, no. 1 (2014): 1-8.

Hasenclever, A. "Geteilte Werte, Gemeinsamer Frieden? Uberlegungen $\mathrm{Zu}$ Zivilisierenden Kraft Von Religionen Und Glaubensgemeinschaften." In Friedenspolitik: Ethisce Grundaglen Internationaler Beziehungen. Munchen: Piper, 2003.

Hassolf, Helen. "The Educational Challege in Education for Sustainable Development: Qualification, Social Change and Political." Malmo University, 2015. 
Hassolf, Helen, Margareta Ekborg, and Claes Marmberg. "Discussing Sustainable Development among Teachers: An Analysis from a Conflict Perspective." International Journal of Environmental \& Science Education 9 (2014): 41-57.

Heslam, Peter S. Creating a Christian Worldview: Abraham Kuyper's Lectures on Calvinism. Grand Rapids: Eerdmans, 1998.

Jackson, Robert. Religious and Education in Europe: Developments, Contexts and Debates. Munchen, Berlin: Waxmann Munster, 2007.

Knight, George. Myths in Adventism: An Interpretive Study of Ellen White, Education and Related Issues. Hagerstown, MD: Review and Herald, 1985.

Knight, George R. "The Aims of Adventist Education: A Historical Perspective." In Adventist Education, General Conference, 2000.

Kuyper, Abraham. Lectures on Calvinism. New York: Cosimo Classics, 2007.

-Wisdom and Wonder: Common Grace in Science and Art. Edited by Jordan J. Ballor and Stephen J. Grabill. Grand Rapids, Michigan: Christian's Library Press, 2011.

Maclean, Angus H., James D. Smart, Relph D. Heim, and Sophia Lyon Faith. "The Theological Dillema in Religious Education." Religious Education 55, no. 3 (1960): 163-173.

Miller, Joyce, Kevin O'Grady, and Ursula McKenna. Religion in Education: Innovation in International Research. London: Routledge Taylor \& Francis Group, 2013.

Niculescu, Rodica Mariana, and Mariana
Norel. "Religious Education an Important Dimension of Human's Education." Procedia-Social and Behavioral Sciences 93 (2013): 338342.

Nuryatno, M. Agus. "Comparing Religious Education in Indonesia and Japan." AlJāmi'ah: Journal of Islamic Studies 52, no. 2 (2014): 435-458.

Patrinos, Harry Anthony. School Choice in the Netherlands, 2011.

Price, Timothy Saun. "Abraham Kuyper and Herman Bavinck on the Subject of Education as Seen in Two Public Addresses." TBR 2 (2011): 59-70.

Roxburgh, Alan J., and Fred Romanuk. The Missional Leader: Equipping Your Church to Reach a Changing World. San Francisco, CA: Jossey-Bass, 2006.

Simmons, John. The Education Dilemma: Policy Issues for Developing Countries in the 1980s. Oxford, New York, Toronto, Sydney, Frankfurt: Pergamon Press, 1980.

Skrzypaszek, John. "The Higher View of Education."

https://research.avondale.edu.au/cgi/v iewcontent.cgi?article $=1068 \&$ context $=$ teach.

Snorrason, Erling Bernhard. "Aims of Education in the Writing of Ellen White." Andrews University, 2005. https://digitalcommons.andrews.edu/c gi/viewcontent.cgi? article $=1706 \&$ con text $=$ dissertations.

White, Ellen. Education. United States: Ellen White Estate Inc., 1903.

Witte, John. "The Biography and Biology of Liberty: Abraham Kuyper and the American Experiment." Koers 64, no. $2 \& 3$ (1999): 173-195. 
Wolhuter, Charl, and Corene de Wet, eds. International Comparative Perspectives on Religion and Education. Bloemfontein: Sun Press, 2014.
Woolf, Beverly Park, H. Chad Lane, Vinay K. Chaudhri, and Janet L. Kolodner. "Al Grand Challenges for Education." AL Magazine, 2015. 